\title{
Combined utilization of red mud and mechanically activated fly ash in geopolymers
}

The Mining-Geology-Petroleum Engineering Bulletin UDC: 66.03

DOI: 10.17794/rgn.2019.1.3

Original scientific paper

\author{
Gábor Mucsi'; Roland Szabó ; Ádám Rácz³; Ferenc Kristály4; Sanjay Kumar ${ }^{5}$ \\ 1,2,3 Institute of Raw Material Preparation and Environmental Processing, University of Miskolc, 3515 Miskolc, Hungary \\ ${ }^{4}$ Institute of Mineralogy and Geology, University of Miskolc, 3515 Miskolc, Hungary \\ ${ }^{5}$ CSIR-National Metallurgical Laboratory, Jamshedpur 831007, India
}

\begin{abstract}
This paper focuses on the investigation of the co-utilization of two major industrial waste materials, power station fly ash and red mud. Experimental studies were carried out to establish the correlation between the physical properties of a geopolymer product and a mixture composition. The effect of mechanical activation and the red mud dosage on the geopolymerisation was investigated. Geopolymerisation of mechanically activated fly ash has been carried out with various proportions of red mud ranging between o-30 \% by weight. The compressive strength of fly ash based geopolymer increased until $15 \%$ of red mud addition. The optimal red mud addition in fly ash geopolymer was determined. The influence of red mud on phase composition and chemical bonds of the resulted geopolymer were determined by XRD analysis and FTIR studies. Due to the geopolymerisation reactions, new phases like hydroxy-cancrinite, faujasite and thenardite appeared in the product.
\end{abstract}

Keywords:

red mud, fly ash, grinding, geopolymer, strength, mineral phases.

\section{Introduction}

Fly ash is a finely dispersed residue of coal combustion collected in electrostatic precipitators in thermal power plants. The particle size distribution of the fly ash mainly depends on the primary mineralogical composition of the fuel coal, the fineness of the coal and boiler conditions. One of the limitations associated with lignite fly ash is the low pozzolanic reactivity which makes them less desirable for use in the construction sector. Thus, to overcome this problem, the reactivity of fly ash can be increased by mechanical activation (Juhász \& Opoczky, 1990; Kumar \&Kumar, 2013; Mucsi et al., 2009). The research on fly ash usability as a secondary raw material is a highly important area today, both for waste management and low cost building material resources. About 800 million tons of CCP (Coal Combustion Products) including fly ash, slag and desulfurization gypsum are generated each year worldwide (Heidrich et al., 2013).

Red mud or in other words "bauxite residue" is the waste generated during Bayer's process of the extraction of alumina from bauxite. There is an estimated 3 billion tons of red mud accumulation globally, increasing with approx. 120 million tons per year (Courtney, 2015).

Corresponding author: Gábor Mucsi

ejtmucsi@uni-miskolc.hu
Since this material is categorized as hazardous waste and its safe disposal requires high cost investments, the research on environmentally friendly industrial recycling is also a key area worldwide. Even if rare and critical elements are aimed for extraction from red muds, it will not consume the bulk volume. Thus, a safer and more favoured way is their use as additives in construction materials, for example as geopolymer raw material since alkali content will react with aluminosilicate bearing phases (Jamieson et al., 2012; McLellan et al., 2011; Mucsi et al., 2015, Singh et al., 2016; Nenadovic et al., 2017).

Geopolymers are a new class of environmentally friendly construction materials with the potential to incorporate both fly ash and red mud. They are amorphous aluminosilicate materials which can be produced by the reaction between silica and aluminosilicate in an alkaline medium $(\mathrm{NaOH}$ and/or $\mathrm{KOH})$ at ambient or higher $\left(30-100{ }^{\circ} \mathrm{C}\right)$ temperature. Due to their simple, energy efficient and eco-friendly production method compared to ordinary Portland cement, good durability and mechanical properties, geopolymers can replace numerous conventional binder and ceramic materials mainly for high-tech applications (fire and acid resistant materials, ceramics with special properties, composites) (Davidovits, 1989; Komintsas \& Zaharaki, 2007, Kumar et al, 2005). 
There are several recently published papers focusing on the synergetic application of fly ash (FA), granulated blast furnace slag, metakaolin combined with red mud as a silicate and alkali resource in the synthesis of geopolymer (Hajjaji et al., 2013; He et al., 2013; He at al., 2012; He \& Zhang, 2011; Hairi et al., 2015; Cundi et al., 2005, Mucsi et al., 2014).

Kumar and Kumar (2013) investigated red mud and fly ash combinations to develop geopolymer products. Red mud addition up to $20 \%$ to fly ash has enhanced the reaction and properties of the resulting geopolymer. Paving blocks using 10-20\% red mud has been developed which meets IS 15658 specification.

Van Riessen et al. (2013) examined various industrial residues to manufacture geopolymers. Geopolymers with a $\mathrm{Si} / \mathrm{Al}$ ratio of 2.3 and a $\mathrm{Na} / \mathrm{Al}$ ratio of 0.8 were targeted. With synthetic Al-plant spent liquor as the alkali activator, geopolymers with a mean compressive strength of $33 \mathrm{MPa}$ were synthesized.

A geopolymer designed by sodium silicate/ $\mathrm{NaOH}$ activation of metakaolin, iron oxide and red mud mixtures was introduced by Hajjaji et al. (2013). They have used red mud up to $25 \%$ in their geopolymer. Red mud influences the mechanical strength during curing (28 days) and showed compressive strength above $10 \mathrm{MPa}$.

Geopolymer from red mud (RM) and rice husk ash (RHA) was produced by He et al. (2013). The mechanical properties of the RM-RHA geopolymers were dependent upon an array of factors, such as alkalinity, raw material mix ratio, curing time, fineness of RHA, and uncertainties involving incomplete geopolymerization. The studied geopolymers have compressive strengths of up to $20.5 \mathrm{MPa}$.

Geopolymers were synthesized from metakaolin and the admixture of RM and FA by He et al. (2012). The metakaolin based geopolymer achieved compressive strength of $31 \mathrm{MPa}$, while the RM bearing geopolymer had a strength of $13 \mathrm{MPa}$. The final products contained a gel-like geopolymer binder as a matrix, but also inherited nonreactive crystalline phases from parent materials and a small amount of unreacted source materials.

He and Zhang (2011) found that depending on the synthesis conditions, the unconfined compressive strength ranges from 3 to $13 \mathrm{MPa}$. The findings suggest that RM and FA, can be reused to produce geopolymers that may replace Portland cement and hence be applied in civil infrastructure construction. Hairi et al. (2015) proved that the RM forms geopolymers through the reaction of aluminate and silicate species in a similar process to that of alkali-activated kaolin. The presence of iron in the RM as hematite did not interfere with geopolymer formation.

Vukcevic et al. (2013) investigated the structure of geopolymer synthesised from RM and metakaolin. The XRD patterns indicated that the geopolymerisation resulted in the dissolution of the starting material and a formation of amorphous and crystalline aluminosilicate phases as well as the stable phases of leucite and kalsilite. Additionally, the existence of non-dissolved solid particles of RM was indicated beside the residual unreacted kaolinite or sodium-aluminosilicate phase.

Dimas et al. (2009) established the effect of synthesis parameters (solid-to-liquid ratio, caustic soda, soluble silica concentrations, and metakaolin addition) on the properties of RM-based inorganic polymeric materials. The results showed that the produced materials have high compressive strength, very low water absorption, satisfactory apparent density, and excellent fire resistance.

In a paper written by $\mathbf{F u}$ and Xiong (2014), a geopolymer was synthetized from sintered RM (30 \%), gypsum $(10 \%)$, calcined bauxite tailings and FA and lime $20 \%$ respectively. The compressive strength of the product was $15.4 \mathrm{MPa}$.

Based on the above studies it can be stated that most research work deals with "raw" fly ash, however, in some cases, this starting material is not appropriate for geopolymerisation, especially the landfilled ones (Mádai et al., 2015) since the reactivity of the initial fly ash is relatively low due to the weathering effect. Therefore, it can be mechanically activated by grinding to be more reactive prior to alkaline activation in order to improve the properties (mechanical stability) of the resulted geopolymer product. The objective of this paper is to reveal the effect of mechanical activation of FA on geopolymer properties. The further aim was to investigate the possibility of substituting the alkali activator and aluminosilicate constituents by the addition of RM.

\section{Materials and methods}

\subsection{Materials}

FA from the lignite based power station (Visonta, Hungary) and RM from Almásfüzitő waste tailing (Hungary) was used for the experiments (Mucsi et al., 2014). Prior to the experimental work, both the FA and RM samples were dried in a drying cabinet overnight. The particle size distribution of the raw and the ground materials was measured by HORIBA LA-950V2 laser diffraction particle size analyzer in wet mode using distilled water as a dispersing media. Calculation of particle size distribution from measured data was carried out using the Mie-theory taking into account the refraction index of the material.

The geometric (outer) specific surface area (SSA) was calculated using particle size distribution (PSD) data by the laser sizer software. The RM sample is characterized as a much finer particle size distribution (median particle size $\left.\mathrm{x}_{50}=2 \mu \mathrm{m}\right)$ than the FA sample $\left(\mathrm{x}_{50}=52 \mu \mathrm{m}\right)$. The moisture content of FA was determined in a drying cabinet overnight at $105{ }^{\circ} \mathrm{C}$, which resulted in a very low value of $0.3 \%$, however the moisture content of the RM sample was significantly higher at $33.6 \%$. The physical properties of the raw materials are given in Table 1. 
Table 1: Physical and mineralogical properties of raw materials

\begin{tabular}{|l|c|c|}
\hline Properties & Fly ash & Red mud \\
\hline Origin & $\begin{array}{c}\text { Visonta, } \\
\text { Hungary }\end{array}$ & $\begin{array}{c}\text { Almásfüzitö, } \\
\text { Hungary }\end{array}$ \\
\hline $\begin{array}{l}\text { Median particle size, } \\
\mu \mathrm{m}\end{array}$ & 52 & 2 \\
\hline Moisture content, \% & 0.3 & 33.6 \\
\hline $\begin{array}{l}\text { Specific surface area, } \\
\mathrm{cm}^{2} / \mathrm{g}\end{array}$ & 1152.1 & 12850.2 \\
\hline Particle density, g/cm ${ }^{3}$ & 1.93 & 3.03 \\
\hline Main minerals & $\begin{array}{c}\text { Quartz, } \\
\text { maghemite, } \\
\text { hematite, } \\
\text { anhydrite, albite } \\
\text { and lime }\end{array}$ & $\begin{array}{c}\text { Hematite, } \\
\text { cancrinite, } \\
\text { gibsite, calcite } \\
\text { and lime }\end{array}$ \\
\hline $\begin{array}{l}\text { Residual alkali content, } \\
\text { mol/1 }\end{array}$ & - & 0.476 \\
\hline
\end{tabular}

The composition of the geopolymer product was investigated by using a JASCO 4200 type Fourier Transformed Infrared Spectrometer (FT-IR) in reflection mode with a diamond ATR PRO470-H attachment. Stretching and bending vibrations of chemical bonds were used to observe the dissolution and transformation of primary components and to detect newly forming materials. Three spectra were recorded from each sub-sample and every sample was measured with 3 sub-samples. One spectrum was averaged over 64 FTIR measurements with, $4 \mathrm{~cm}^{-1}$ resolution number. The beam incidence angle was $45^{\circ}$, TGS detector was used with a scanning speed of $2 \mathrm{~mm} / \mathrm{sec}$.

The mineralogical composition was determined by a Bruker D8 Advance XRD powder diffractometer $(\mathrm{Cu}-$ $\mathrm{K} \alpha$ radiation, $40 \mathrm{kV}, 40 \mathrm{~mA}$ ) in parallel beam geometry (Göbel-mirror). Patterns were recorded in $2-70^{\circ}(2 \theta)$ range, with $0.007^{\circ}(2 \theta)$ steps in 42 seconds, with a Vantec-1 position sensitive detector $\left(1^{\circ}\right.$ window opening). Phase identification was made by Search/Match (multiple iteration) on ICDD PDF2 (2005). Quantitative evaluation was made by Rietveld-refinement in TOPAS4 software, using FPM based instrumental convolution (using SRM 640d Si), with crystal structure data from the AMCSD database.

The residual alkali content of the RM sample was analysed by titration of the aqueous extract. The result shows that $1 \mathrm{~kg}$ RM contains $286 \mathrm{ml}$ alkali with a concentration of $0.476 \mathrm{~mol} / \mathrm{l}$.

The chemical composition of the lignite FA was determined using a Rigaku Supermini X-ray Fluorescence apparatus. After determination of loss on ignition
(L.O.I.), $1.000 \mathrm{~g}$ burned powder sample was mixed with $6.000 \mathrm{~g}$ of lithium tetraborate $\left(\mathrm{Li}_{2} \mathrm{~B}_{4} \mathrm{O}_{7}\right)$ which explore metals in powder. The melted mixture analyzed by $\mathrm{Fu}-$ sion bead oxide method built in XRF software. Every sample was analyzed 3 times; these values were averaged.

The results are found in Table 2. The FA is characterized with a relatively low $\mathrm{SiO}_{2}$ content $(45.85 \%)$, additionally $\mathrm{Fe}_{2} \mathrm{O}_{3}(12.15 \%)$ and $\mathrm{Al}_{2} \mathrm{O}_{3}(16.82 \%)$ content was high compared to brown coal fly ash.

\subsection{Methods}

Systematic experimental series were carried out in the framework of the research focusing on the following questions:

- the effect of mechanical activation of FA on geopolymer strength and density, as well as the investigation of the correlation between the properties;

- development of RM - FA geopolymer and study of its physical and structural properties.

The mechanical activation experiments of FA were carried out in a conventional tumbling laboratory ball mill with the size of $\varnothing 305 \times 305 \mathrm{~mm}$ (smooth walled), with steel balls (minimum and maximum ball size was $12 \mathrm{~mm}$ and $50 \mathrm{~mm}$ respectively) as a grinding media. The mill filling ratio of the grinding media was $30 \mathrm{~V} / \mathrm{V}$ $\%$, the material filling ratio was $110 \mathrm{~V} / \mathrm{V} \%$. Residence time of mechanical activation was 5, 10, 20, 30 and 60 minutes.

Geopolymer specimens were prepared by mixing FA and a $\mathrm{NaOH}$ solution (and $\mathrm{RM}$ ) using 0.67 liquid/solid ratio. The paste was placed in a pre-oiled mould and compacted by vibration. The compacted geopolymer paste was kept in the mould for 24 hours in sealed conditions at ambient temperature, before removing the specimens. This was followed by heat curing at $90{ }^{\circ} \mathrm{C}$ for 6 hours. The uniaxial compressive strength of the geopolymer was determined by a Compression Testing Machine at the age of 7 days. Five specimens were prepared in each case.

\section{Results and discussion}

\subsection{Mechanical activation of fly ash}

The primary effect of the mechanical activation of fly ash by grinding in this case was the particle size decrease and specific surface area increase. After 60 minutes, a grinding $11.6 \mu \mathrm{m}$ median particle size was achieved from the initial value of $52.04 \mu \mathrm{m}$, indicating a $4.49\left(\mathrm{r}_{50}\right)$

Table 2: Chemical composition of fly ash samples for main components

\begin{tabular}{|l|c|c|c|c|c|c|c|c|c|}
\hline & $\mathrm{SiO}_{2}$ & $\mathrm{Fe}_{2} \mathrm{O}_{3}$ & $\mathrm{Al}_{2} \mathrm{O}_{3}$ & $\mathrm{CaO}$ & $\mathrm{MgO}$ & $\mathrm{Na}_{2} \mathrm{O}$ & $\mathrm{K}_{2} \mathrm{O}$ & $\mathrm{SO}_{3}$ & L.O.I. \\
\hline Lignite fly ash & 45.85 & 12.05 & 16.82 & 12.97 & 2.90 & 0.50 & 1.83 & 3.76 & 2.25 \\
\hline Red mud & 7.52 & 25.13 & 19.24 & 22.84 & n.a. & 5.75 & n.a. & n.a. & 12.54 \\
\hline
\end{tabular}


size reduction ratio. Additionally, the "outer" specific surface area increased significantly from $1152.1 \mathrm{~cm}^{2} / \mathrm{g}$ up to $5425.6 \mathrm{~cm}^{2} / \mathrm{g}$ due to ball milling. The effect of grinding on the FA fineness (median and $\mathrm{x}_{80}$ particle size) can be seen in Figure 1. It can be clearly observed that both characteristic size increases significantly until 20 min residence time, then the intensity of the reduction is moderated. However, there is no aggregation or agglomeration based on this data.

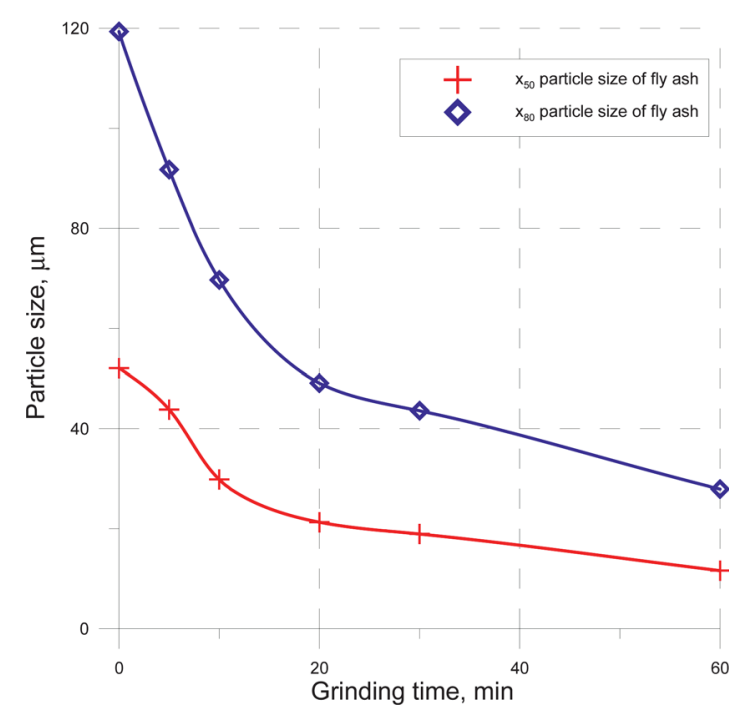

Figure 1: Characteristic particle size of ground fly ash as function of grinding time

A significant increase in the particle density was observed as a function of grinding time from the initial value of $1.93 \mathrm{~g} / \mathrm{cm}^{3}$ up to $2.26 \mathrm{~g} / \mathrm{cm}^{3}$ after 20 minutes residence time. It can be explained by the porous structure of FA, which after size reduction turned into compact spherules, hence decreasing the pore volume between the bulk particles and increasing the particle density.

Based on raw and milled fly ash FT-IR spectra (see Figure 2) significant absorbance can be observed at

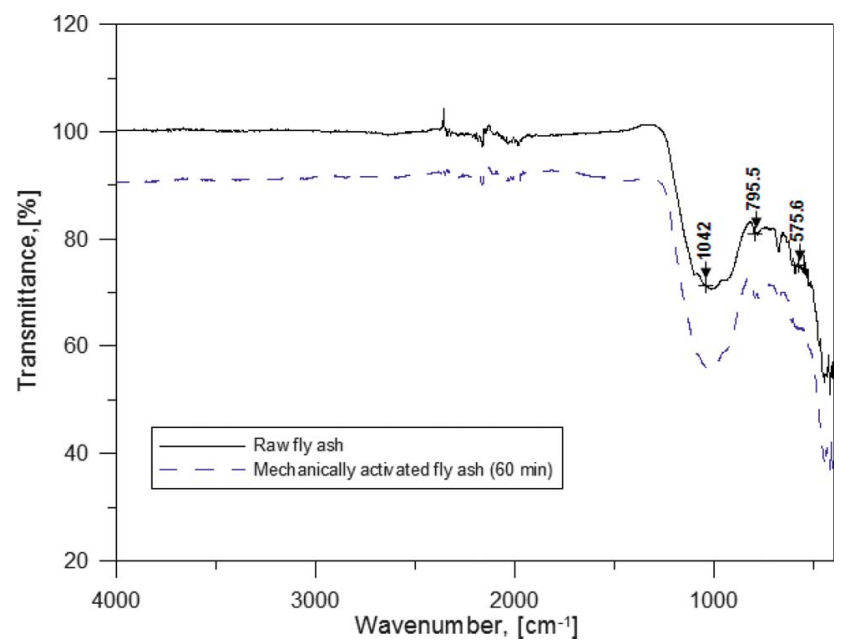

Figure 2: FTIR spectra of the raw and grounded fly ash (y-axis shifted for visualisation)
$1042 \mathrm{~cm}^{-1}$ and $575 \mathrm{~cm}^{-1}$, related to T-O-T (T=Si, or Al) bonds asymmetric and symmetric stretching vibration. The peak belongs to $795 \mathrm{~cm}^{-1}$, related to Si-O-Si bonds symmetric stretching vibration while at $734 \mathrm{~cm}^{-1}$ signed $\mathrm{Si}-\mathrm{O}-\mathrm{Si}$ and Al-O-Si bonds symmetric stretching vibration (Mucsi et al., 2015). This minor change in FTIR spectra indicates no significant transformation in the fly ash structure after grinding, so it can be concluded that the reactivity improvement belongs to specific surface area (reaction surface) increase.

\subsection{Geopolymer from mechanically activated fly ash}

The effect of FA fineness on geopolymer compressive strength was investigated on specimens obtained using 6 $\mathrm{M}$ concentration $\mathrm{NaOH}$ solution which is shown in Figure 3. This relationship can be described by a logarithmic function. The fitting results are as follows:

$$
Y=3.89 \times \ln (X)-25.10
$$

with the coefficient of correlation, R-square of 0.79 .

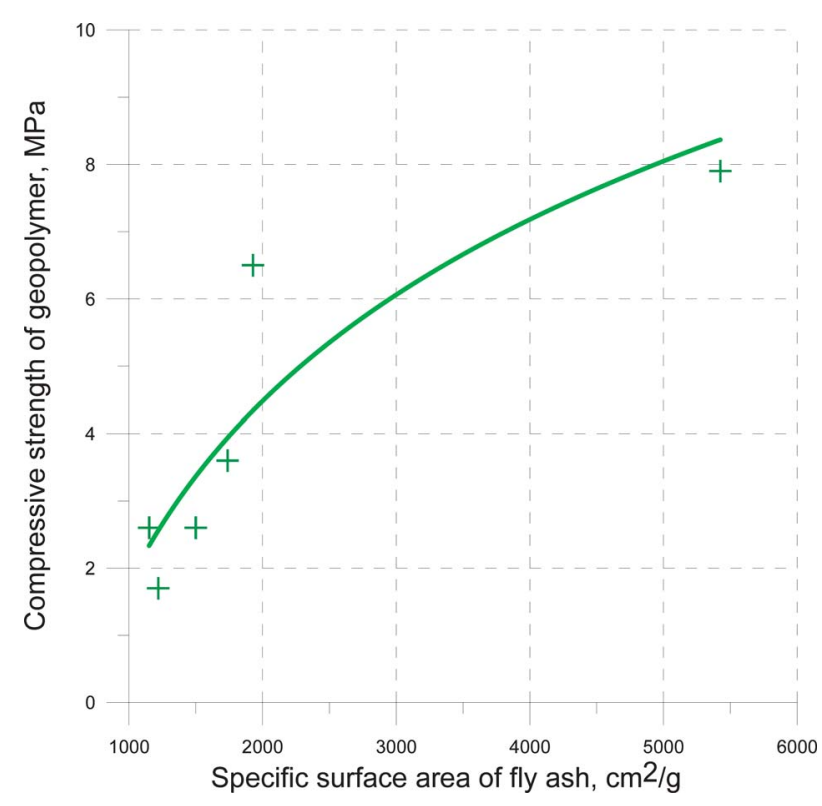

Figure 3: Effect of fly ash fineness on geopolymer compressive strength

The compressive strength of the resulted geopolymer increased from the initial 2.6 MPa up to $6.5 \mathrm{MPa}$ due to mechanical activation for 30 minutes grinding time which was a relatively intensive section. This can be explained with the higher reaction surface generated by grinding, i. e. more reaction partner of the alkaline activator was liberated. Furthermore, the 60 minutes ground FA based geopolymer strength was $21.5 \%$ higher than that of the product consisting of 30 minutes ground FA. The highest geopolymer compressive strength was 7.9 MPa using $6 \mathrm{M} \mathrm{NaOH}$ solution as the alkaline activator and 60 minutes ground FA. Furthermore, the relationship between the compressive strength and specimen 
density was investigated which is shown in Figure 4. This relation can be described using a linear function with the following equation:

$$
Y=30.78 \times X-34.63
$$

where the coefficient of correlation, R-square was 0.95 . Based on this linear characteristic curve a strong correlation was found between the geopolymer compressive strength and its specimen density.

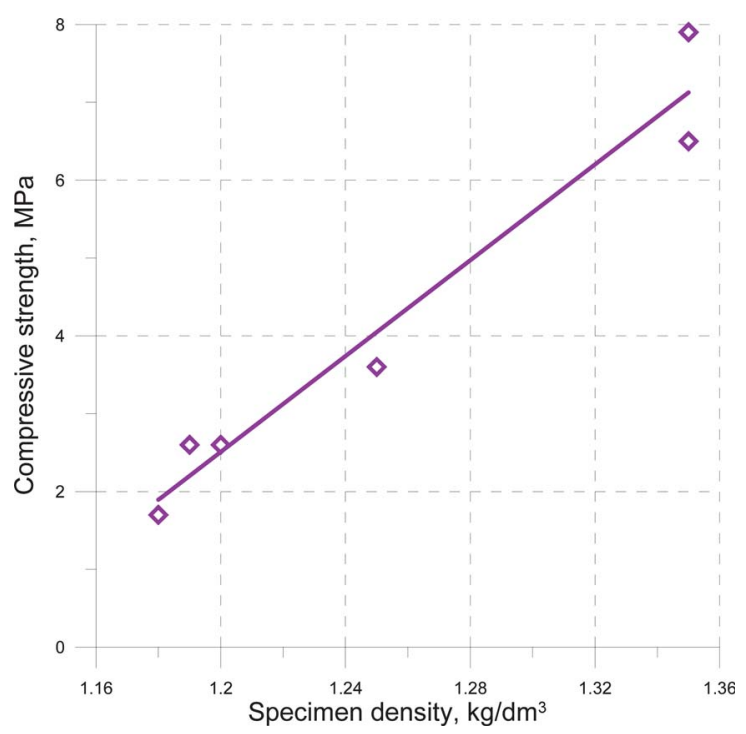

Figure 4: The relationship between compressive strength and specimen density of mechanically activated fly ash based geopolymer

Figure 5 shows the FTIR spectra of the raw and ground lignite FA based geopolymer. Four new peaks appeared due to geopolymerisation (at 3375, 1651, 1415 and $877 \mathrm{~cm}^{-1}$ ), another shifted to lower wave number $\left(957 \mathrm{~cm}^{-1}\right)$ and changed its intensity. The peak at 3375 $\mathrm{cm}^{-1}$ corresponds to $-\mathrm{OH}, \mathrm{HOH}$ bonds stretching vibration, the peak at $1651 \mathrm{~cm}-1$ to $\mathrm{HOH}$ bonds bending vibration, while the bands at $877 \mathrm{~cm}^{-1}$ are related to $\mathrm{Si}-\mathrm{O}$ stretching and $\mathrm{OH}$ bending bond vibrations $(\mathrm{Si}-\mathrm{OH})$.

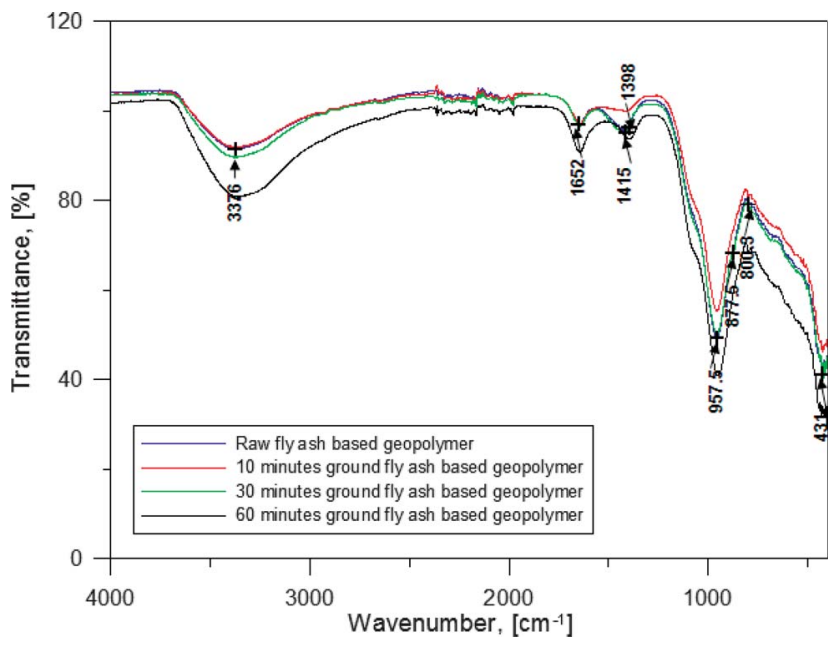

Figure 5: FTIR spectra of lignite fly ash based geopolymers
The peak at $1415 \mathrm{~cm}^{-1}$ corresponds to O-C-O stretching vibration, the carbonate group in Na-carbonate phases (see XRD results). The peak observed at $1012 \mathrm{~cm}^{-1}$ shifts to a lower wave number $\left(957 \mathrm{~cm}^{-1}\right)$ after geopolymerisation, indicating structural reorganization. It is associated with dissolution of the amorphous phase of FA in strong alkali media according to Panias et al. (2007).

\subsection{Fly ash - red mud based geopolymer}

\subsubsection{Physical properties}

During the preparation of the geopolymer paste, RM was added in $5,10,15,20,25$ and $30 \%$ portion by mass of the dry mass of FA. The alkaline activator $\mathrm{NaOH}$ with $6 \mathrm{M}$ concentration was used in different liquid to solid ratios depending on the workability of the paste. Namely for geopolymer paste containing $5 \% \mathrm{RM}$, the activator was added in $40 \%$, for that of 10,15 and $20 \%$, the activator was added in $35 \%$, finally for 25 and $30 \% \mathrm{RM}$, the $\mathrm{NaOH}$ solution was added in $30 \%$.

Figure 6 demonstrates the relationship between compressive strength and specimen density of RM - FA based geopolymer which can be described using a linear function with the following equation:

$$
Y=19.04 \times X-19.63
$$

The coefficient of correlation, R-squared was relatively low 0.71 . It was observed that the higher the specimen density of geopolymer, the higher its compressive strength, similarly to Figure 4.

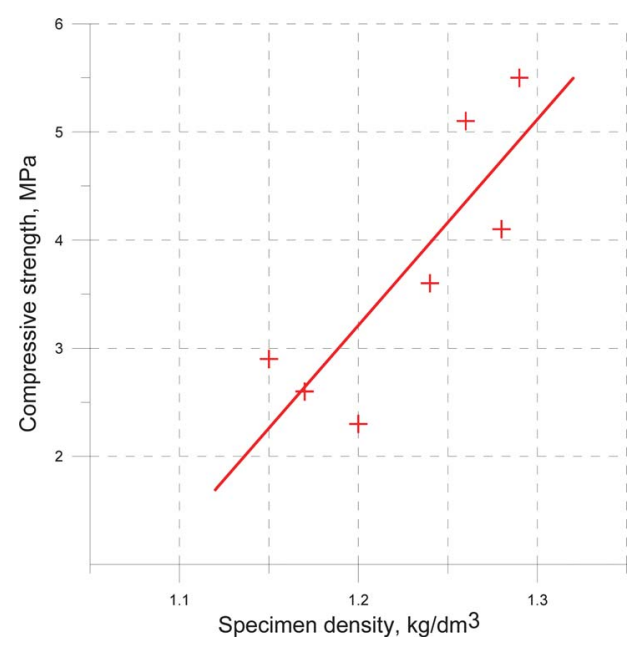

Figure 6: Relationship between compressive strength and specimen density of red mud - fly ash based geopolymer

The strength values have a maximum point at $15 \%$ $\mathrm{RM}$ content, which was $5.5 \mathrm{MPa}$. Additionally, it was observed that the characteristic red color of RM was dominant in the final product (see Figure 7). It might be an advantage if the commercialized product will be manufactured, since colored tiles generally have a higher price due to the pigments they contain. 


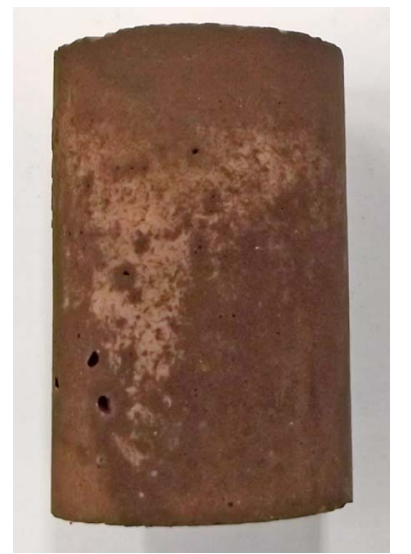

Figure 7: Red mud fly ash based geopolymer specimen (15\% RM)

\subsubsection{Material composition}

ATR-FTIR spectra of geopolymer specimens containing RM in different amounts can be seen in Figure 8. Peaks at $3390-3370 \mathrm{~cm}^{-1}$ are related to $-\mathrm{OH}, \mathrm{H}-\mathrm{O}-\mathrm{H}$ bonds stretching vibration, at $1640 \mathrm{~cm}^{-1}$ corresponds to $\mathrm{H}-\mathrm{O}-\mathrm{H}$ bending vibration. These bands are indicative for chemically bonded water and functional $\mathrm{OH}$ - groups (Panias et al. 2007; Mucsi et al., 2015).

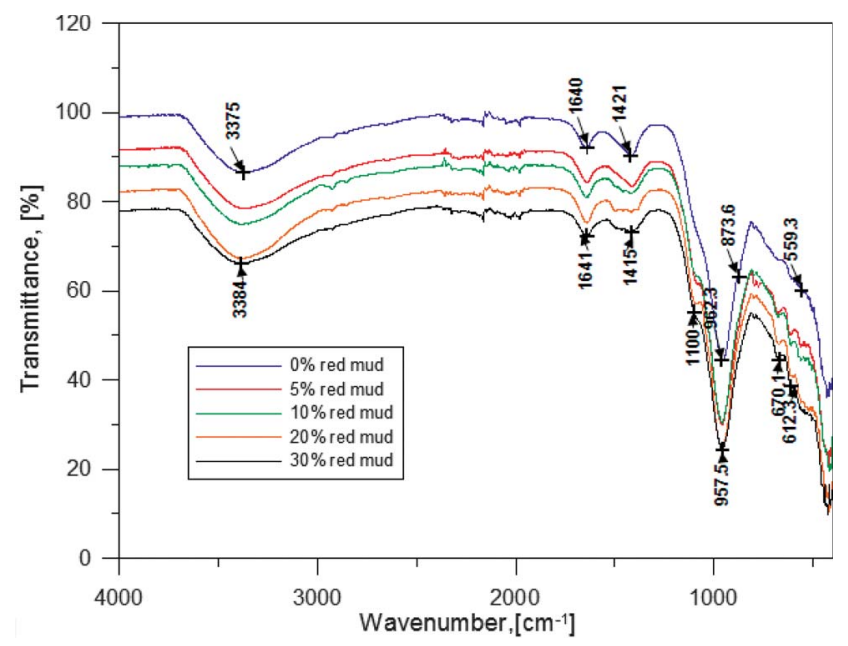

Figure 8: FTIR spectras of FA-RM based geopolymer ( $\mathrm{y}$-axis shifted for visualisation)

Peaks at $1410-1425 \mathrm{~cm}^{-1}$ belong to O-C-O stretching vibration of carbonate group, which is formed from the remaining unreacted activator solution and $\mathrm{CO}_{2}$. Peaks at $1100-445 \mathrm{~cm}^{-1}$ are related to $\mathrm{Si}-\mathrm{O}-\mathrm{Si}, \mathrm{Al}-\mathrm{O}-\mathrm{Si}$ asymmetric and symmetric stretching and bending vibrations. As a result of RM addition, some bands (peak $559 \mathrm{~cm}^{-1}$ ) disappeared, while others $\left(670,612 \mathrm{~cm}^{-1}\right)$ appeared, indicating newly formed compounds. It shows that slight differences in newly formed phases can be observed due to RM addition. However, the most significant change was detected concerning the carbonate peak which was shifted from 1421 to $1414 \mathrm{~cm}^{-1}$, at the same time, the peak intensity decreased due to RM addition indicating the change in the concentration of carbonate compounds.
Table 3: FTIR peak wavenumbers and bonds

\begin{tabular}{|l|l|}
\hline \multicolumn{1}{|c|}{ Wavenumber } & \multicolumn{1}{c|}{ Bonds } \\
\hline $3390-3370 \mathrm{~cm}^{-1}$ & $-\mathrm{OH}, \mathrm{H}-\mathrm{O}-\mathrm{H}$ bonds stretching vibration \\
\hline $1640 \mathrm{~cm}^{-1}$ & H-O-H bending vibration \\
\hline $1410-1425 \mathrm{~cm}^{-1}$ & $\begin{array}{l}\text { O-C-O stretching vibration of carbonate } \\
\text { phase }\end{array}$ \\
\hline $1100-445 \mathrm{~cm}^{-1}$ & $\begin{array}{l}\text { Si-O-Si, Al-O-Si asymmetric and } \\
\text { symmetric stretching and bending } \\
\text { vibrations }\end{array}$ \\
\hline $559 \mathrm{~cm}^{-1}$ & disappeared \\
\hline $670,612 \mathrm{~cm}^{-1}$ & appeared \\
\hline 1421 to $1414 \mathrm{~cm}^{-1}$ & $\begin{array}{l}\text { carbonate peak which was shifted } \\
\text { peak intensity decreased showing } \\
\text { change in the concentration of } \\
\text { carbonate compounds }\end{array}$ \\
\hline
\end{tabular}

Table 3 contains the characteristic peak wavenumbers and types of bonds.

The changes in crystalline phase composition were influenced by the RM amount (see Figure 9). In the FA based geopolymer without RM, significant thénardite and thermonatrite were formed, as a result of excess $\mathrm{NaOH}$ reported to a low alkaline activity glass phase in the FA. The carbonate phase evolves from the air trapped in the geopolymer matrix, while the sulphate phase consumes the $\mathrm{S}$ available in soluble form (e.g. anhydrite). Nonetheless, geopolymerisation takes place in the pure geopolymer ( $0 \% \mathrm{RM}$ sample), as indicated by the increase in amorphous content and formation of Na-zeolite phases. By the evolution of these phases in the RM containing mixtures, we can estimate the effect of hematite and cancrinite (main constituents of RM) on the geopolymerisation reactions.

Figures 10 a-d show the variation of the main mineral phases of FA-RM geopolymer as a function of RM dosage. First of all, RM addition to FA is considered as a dilution process, since the crystalline components are different (like cancrinite and gibbsite) or at least in different amount (like hematite and calcite). Based on this, we can calculate in what manner the FA quantitative mineralogical composition is expected to change by this dilution, compared to that actually measured by XRD. Performing this step, several constituents, like quartz, albite, hematite and microcline are found which in most cases show little deviation between the calculated and measured diluted amounts. In those mixtures, where larger differences are observed, the evolution of newly formed phases, like hydroxy-cancrinite, faujasite and thenardite have to be examined in detail.

Significantly lower quartz, albite and microcline amounts were found in the mixture with $5 \% \mathrm{RM}$ added. In this mixture, a high increase in hydroxy-cancrinite is detected, in parallel to calcite, quartz and albite "consumption". Even the measured amount of cancrinite added to the mixture is well below the expected value, together with the gibbsite. This indicates a fast hydroxy- 


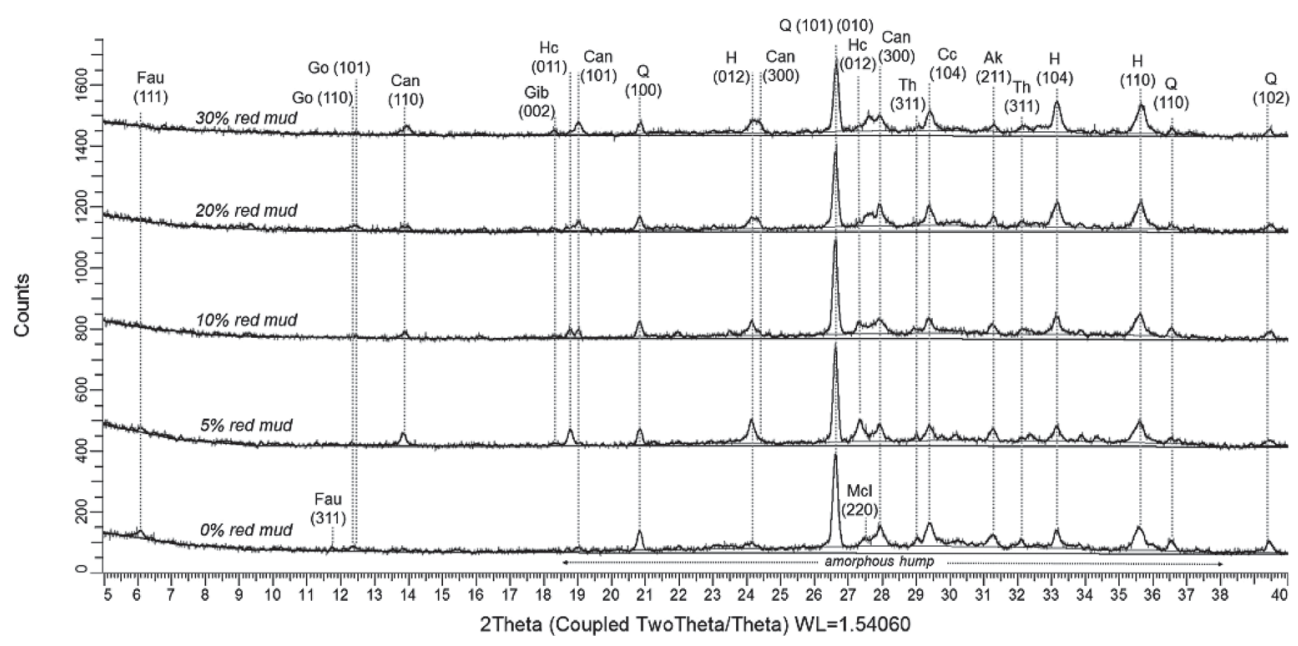

Figure 9: XRD pattern of fly ash - red mud based geopolymers with the most important peaks (Fau - faujasit, Go - gobbinsite, Can - cancrinite, Gib - gibbsite, Hc - hydroxylcancrinite, Q - quartz, $\mathrm{H}$ - hematite, Th - thermonatrite, $\mathrm{Cc}$ - calcite, Ak - akermanite) (y-axis shifted for visualisation)

Table 4: Phase composition of the geopolymer samples, in weight percent as calculated by Rietveld refinement

\begin{tabular}{|c|c|c|c|c|c|}
\hline Phase name, chemical formula and its PDF file nr./RM \% & 0 & 5 & 10 & 20 & 30 \\
\hline Quartz $\mathrm{SiO}_{2}$ PDF 46-1045 & 18.3 & 14.9 & 16.5 & 13.9 & 11.3 \\
\hline Albite $(\mathrm{Na}, \mathrm{Ca}) \mathrm{Al}(\mathrm{Si}, \mathrm{Al})_{3} \mathrm{O}_{8} \mathrm{PDF} 41-1480$ & 8.8 & 6.6 & 9.5 & 7.5 & 3.9 \\
\hline Cancrinite-OH Na $8\left(\mathrm{Al}_{6} \mathrm{SiO}_{24}\right)(\mathrm{OH})_{1.4}\left(\mathrm{CO}_{3}\right)_{0.3}\left(\mathrm{H}_{2} \mathrm{O}\right)_{6.35}$ PDF 88-1931 & - & 15.3 & 6.0 & 0.0 & 1.0 \\
\hline Faujasite- $\mathrm{Na} \mathrm{K}_{69.8} \mathrm{Al}_{69.8} \mathrm{Si}_{122.2} \mathrm{O}_{384}$ PDF 26-0893 & 2.1 & 1.5 & 0.5 & 0.5 & 0.3 \\
\hline Calcite $\mathrm{CaCO}_{3}$ PDF 05-0586 & 10.1 & 5.4 & 5.6 & 7.1 & 6.4 \\
\hline Hematite $\alpha-\mathrm{Fe}_{2} \mathrm{O}_{3}$ PDF 33-0664 & 6.0 & 7.3 & 7.3 & 10.3 & 12.5 \\
\hline Maghemite $\gamma-\mathrm{Fe}_{2} \mathrm{O}_{3}$ PDF 39-1346 & 1.5 & 3.4 & 0.0 & 0.5 & 0.6 \\
\hline Akermanite-(Al) $\mathrm{Ca}_{2}\left(\mathrm{Mg}_{0.75} \mathrm{Al}_{0.25}\right)\left(\mathrm{Si}_{1.75} \mathrm{Al}_{0.25} \mathrm{O}_{7}\right)$ PDF 79-2424 & 5.3 & 5.1 & 4.2 & 3.8 & 3.7 \\
\hline Magnesioferrite $\left(\mathrm{Mg}_{0.146} \mathrm{Fe}_{0.854}\right)\left(\mathrm{Fe}_{0.573} \mathrm{Mg}_{0.427}\right)_{2} \mathrm{O}_{4}$ PDF 89-6187 & 4.9 & 1.3 & 5.6 & 5.1 & 4.3 \\
\hline Gobbinsite $\mathrm{Na}_{3} \mathrm{Al}_{3} \mathrm{Si}_{5} \mathrm{O}_{16} \cdot 6 \mathrm{H}_{2} \mathrm{O}$ PDF $25-0779$ & 0.5 & 0.0 & 0.5 & 1.9 & 0.0 \\
\hline Thenardite $\mathrm{Na}_{2} \mathrm{SO}_{4}$ PDF 74-2036 & 2.9 & 1.6 & 2.5 & 3.7 & 4.0 \\
\hline Thermonatrite $\mathrm{Na}_{2} \mathrm{CO}_{3} \cdot \mathrm{H}_{2} \mathrm{O}$ PDF 08-0448 & 2.4 & 0.9 & 0.9 & 0.9 & 1.9 \\
\hline Microcline $\mathrm{K}\left(\mathrm{AlSi}_{3}\right) \mathrm{O}_{8}$ PDF 76-1238 & 3.5 & 2.8 & 2.9 & 3.9 & 2.8 \\
\hline zeolite-LTA (or A) $\mathrm{Na}_{12} \mathrm{Al}_{12} \mathrm{Si}_{12} \mathrm{O}_{48}\left(\mathrm{H}_{2} \mathrm{O}\right)_{27}$ PDF 73-2340 & 0.6 & 0.9 & 0.1 & 0.2 & 0.1 \\
\hline Cancrinite $\mathrm{Na}_{6}\left(\mathrm{Al}_{6} \mathrm{Si}_{6} \mathrm{O}_{24}\right)\left(\mathrm{CaCO}_{3}\right)\left(\mathrm{H}_{2} \mathrm{O}\right)_{2}$ PDF 71-0776 & & 4.3 & 5.0 & 11.3 & 13.6 \\
\hline Gibbsite $\alpha-\mathrm{Al}(\mathrm{OH})_{3}$ PDF 33-0018 & & 0.8 & 0.9 & 0.3 & 1.6 \\
\hline amorphous & 33.0 & 28.0 & 32.0 & 29.0 & 32.0 \\
\hline
\end{tabular}

cancrinite crystallization. Crystallization takes place on the surface of cancrinite grains, catalyzing the process, and the newly formed phase is built up from the dissolved quartz ( $\mathrm{Si}$ soruce) and calcite ( $\mathrm{Ca}$ source). The high intensity of reactions is also observed by the magnesio-ferrite dissolution and piking maghemite content, formed by the reprecipitation of solubilized Fe. The excess $\mathrm{Mg}$ could be fixed by the hydroxy-cancrinite structure or in the residual amorphous gel, similarly to dissolved albite and microcline.

The high intensity alkaline reaction series in the $5 \%$ RM mixture is generated by the overlapping effect of high $\mathrm{NaOH}$ solution (activator) and cancrinite nanocrys- tals (precipitation centers). As the $\mathrm{NaOH}$ solution amount is decreased, the precipitation is shifted towards Na-sulphate and amorphous phase formation, with decreasing cancrinite type phases. The Fe bearing phases also show an inversion towards magnesio-ferrite precipitation, from the partly dissolved hematite and $\mathrm{Mg}$, probably extracted from the glass phase of FA.

As observed on the calculated to measured amount of amorphous phase, geopolymerisation is heavily catalyzed by the RM addition. After the $\mathrm{NaOH}$ concentration is too low for cancrinite type phases to increase in amount, starting from the mixture with $10 \% \mathrm{RM}$, the amorphous phase formation is significantly higher. Zeo- 

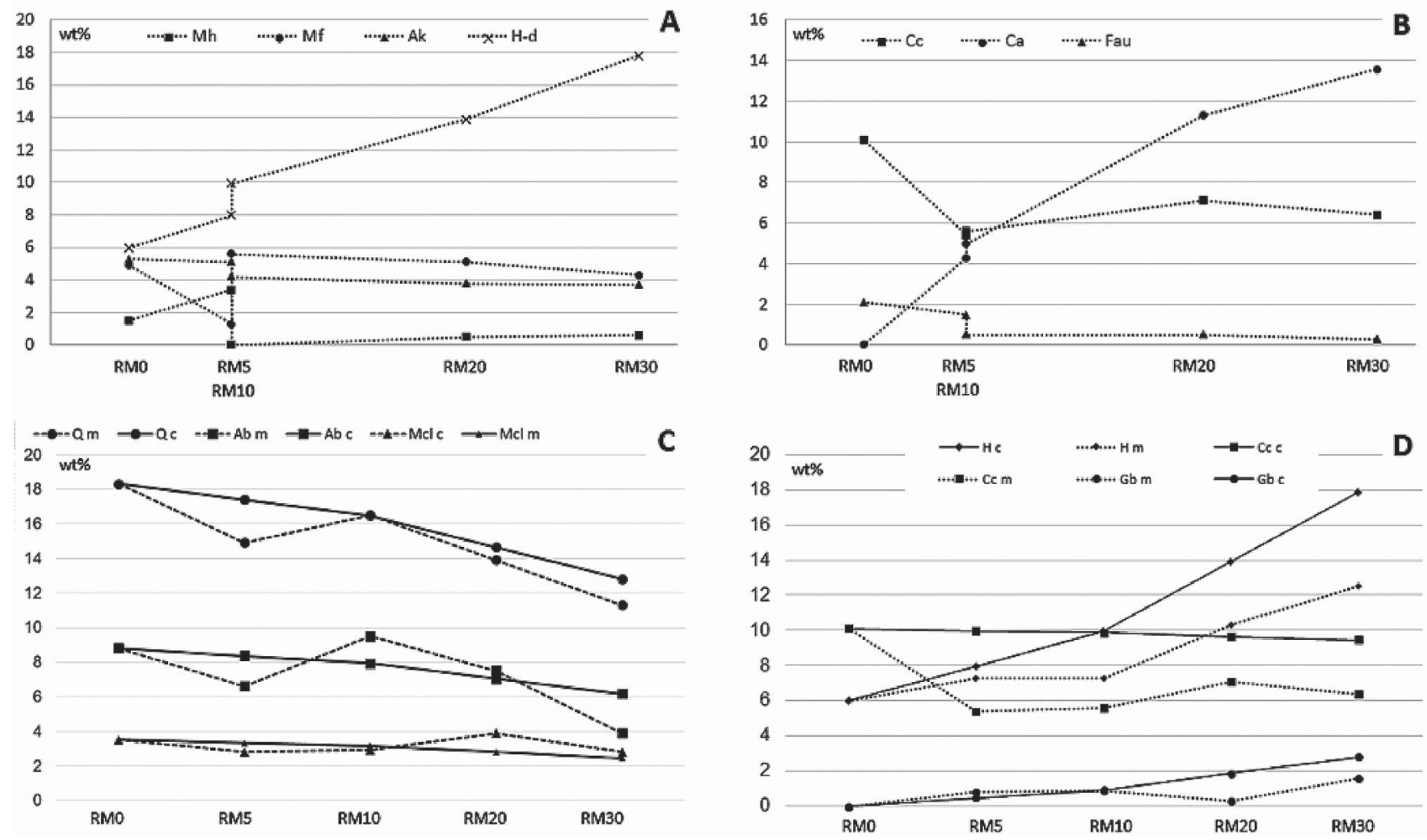

Figure 10 a-d: Variation of the main mineral phases of FA-RM geopolymer as a function of red mud dosage (A: Mh - maghemite, Mf - magnesioferrite, Ak - akermanite, $\mathrm{H}-\mathrm{d}$ - hematite; B: Cc - calcite, Ca - cancrinite, Fau - Faujasite; C: Q m - quartz measured, Q c - quartz calculated, Ab m - albite measured, Ab c - albite calculated, Mcl c - microcline calculated, Mcl m - microcline measured; D: H c - hematite calculated, $\mathrm{H}$ m - hematite measured, Cc c - cancrinite calculated, Cc m - cancrinite measured, Gb m - gibbsite measured, Gb c - gibbsite calculated)

lite formation is inhibited in the optimal 10 to $20 \mathrm{~m} / \mathrm{m} \%$ $\mathrm{RM}$ addition, which resulted in the highest compressive strength of geopolymer specimens.

\section{Acknowledgment}

The described article was carried out as part of the "Sustainable Raw Material Management Thematic Network - RING 2017", EFOP-3.6.2-16-2017-00010 project in the framework of the Széchenyi2020 Program. The realization of this project is supported by the European Union, co-financed by the European Social Fund. This work was partially supported by the János Bolyai Research Scholarship of the Hungarian Academy of Sciences. The authors greatly appreciate the help in compressive strength investigation and laboratory assistance for Dr. Ákos Debreczeni and Mr. Zoltán Molnár respectively.

\section{Conclusions}

Based on the results of the laboratory investigation, the following conclusions are drawn. Mechanical activation of FA enhanced the reactivity and consequently the properties of the resulted geopolymer, i. e. the compressive strength was improved by two times and specimen density increased as well. Good correlation was found between compressive strength and specimen density of geopolymer in case of mechanically activated FA based and RM bearing ones. RM can substitute the alkali activator and FA (aluminosilicate phase) in $10-15 \%$. Additionally, compressive strength increased due to RM addition by 2.5 times. Phase composition changes are determined by RM and activator ratio, inhibits zeolite formation which leads to a compressive strength increase.

\section{References}

Courtney, R. (2015): Neutralisation, revegetation and beyond: an overview of a decade of bauxite residue research. In: Yiannis Pontikes (Ed.) Proceedings of the Bauxite Residue Valorisation and Best Practices Conference. Leuven, Belgium, October 5-7. 2015, ISBN - number: 9789460189784 , pp. 27-34.

Cundi, W, Hirano, Y, Terai, T., Vallepu, R, Mikuni, A. and Ikeda, K. (2005): Preparation of geopolymeric monoliths from red mud-PFBC ash fillers at ambient temperature, Proceedings of the World Congress of Geopolymer 2005, St.-Quentin, France, 85-89.

Davidovits, J. (1989): Geopolymers and geopolymeric materials. Journal of Thermal Analysis, 35, 2, 429-441.

Dimas, D.D., Giannopoulou, I.P., Panias, D. (2009): Utilization of alumina red mud for synthesis of inorganic poly- 
meric materials. Mineral Processing and Extractive Metallurgy Review 30:211-239.

DOI: $10.1080 / 08827500802498199$

Fu, Y., Xiong, Y. (2014): Red mud based geopolymer and its forming mechanism. Applied Mechanics and Materials, 538, 28-31, doi: 10.4028/www.scientific.net/AMM.538.28

Hairi, S. N. M., Jameson, G.N.L., Rogers, J.J., MacKenzie, K.J.D. (2015): Synthesis and properties of inorganic polymers (geopolymers) derived from Bayer process residue (red mud) and bauxite. J Mater Sci, 50, 7713-7724, doi: 10.1007/s10853-015-9338-9

Hajjaji, W., Andrejkovičová, S., Zanelli, C., Alshaaer, M., Dondi, M., Labrincha, J. A., Rocha, F. (2013): Composition and technological properties of geopolymers based on metakaolin and red mud. Mater. Des, 52, 648-654, doi: 10.1016/j.matdes.2013.05.058

He, J., Jie, Y., Zhang, J., Yu, Y., Zhang, G. (2013): Synthesis and characterization of red mud and rice husk ash-based geopolymer composites. Cement and Concrete Composites, 37, 108-118, doi:10.1016/j.cemconcomp.2012.11.010

He, J., Zhang, J., Yu, Y., Zhang, G. (2012): The strength and microstructure of two geopolymers derived from metakaolin and red mud-fly ash admixture: A comparative study. Constr. Build. Mater., 30, 80-91, doi:10.1016/j.conbuildmat.2011.12.011

He, J. and Zhang, G. (2011): Geopolymerization of Red Mud and Fly Ash for Civil Infrastructure Applications, 12871296, doi: 10.1061/41165(397)132

Heidrich, C., Feuerborn, H.J., Weir, A. (2013): Coal combustion products: a global perspective. World of Coal Ash Conference. April 22 -25. 2013, in Lexington, 1-17.

Jamieson, E., Van Riessen, A., Kealley, C., \& Hart, R. (2012): Development of Bayer Geopolymer Paste and use as Concrete. 9th International Alumina Quality Workshop, March 2012, Perth. pp. 296-299.

Juhász, A. Z. and Opoczky, L. (1990): Mechanical Activation of Minerals by Grinding. Akadémiai Kiadó - Ellis, Horwood Ltd Publishers. Budapest - Chichester.

Komintsas, K. Y., Zaharaki, D. (2007): Geopolymerisation: a review and prospects for the mineral industry. Miner. Eng., 20, 1261-1277.

Kumar, A. and Kumar, S. (2013): Development of paving blocks from synergistic use of red mud and fly ash using geopolymerisation. Construction and Building Materials 38, 865-871.

Kumar, S. and Kumar, R. (2011): Mechanical activation of fly ash: Effect on reaction, structure and properties of resulting geopolymer. Ceramics International, 37, 533-541.

Kumar, S., Kumar, R., Alex, T. C., Bandopadhyay, A., Mehrotra, S. P. (2005) Effect of Mechanically Activated Fly ash on the Properties of Geopolymer Cement. Proceedings of the World Congress Geopolymer 2005, Geopolymer Institute, France, 113-116.
Mádai, F., Kristály, F., and Mucsi, G. (2015): Microstructure, mineralogy and physical properties of ground fly ash based geopolymers. Ceramics - Silikáty, 59, 1, 76-85.

McLellan, B., Williams, R., Lay, J., van Riessen, A., \& Corder, G. (2011): Costs and carbon emissions of geopolymer pastes in comparison to ordinary Portland cement. Journal of Cleaner Production, 19, 9-10, 1080-1090.

Mucsi, G., Csőke, B., Gál, A. and Szabó, M. (2009): Mechanical activation of lignite fly ash and brown coal fly ash and their use as constituents in binders. Cement International, 7, 4, 76-85.

Mucsi, G., Lakatos, J., Molnár, Z. and Szabó, R. (2014): Development of geopolymer using industrial waste materials. In: The 9th International Conference Environmental Engineering, Book Series: International Conference on Environmental Engineering (ICEE) Selected papers, 22. 5. 2014. - 23. 5. 2014., Article number: enviro.2014.039 Vilnius, Vilnius Gediminas Technical University. eISSN 2029-7092 / eISBN 978-609-457-640-9, http://dx.doi. org/10.3846/enviro.2014.039

Mucsi, G., Kumar, S., Csőke, B., Kumar, R., Molnár, Z., Rácz, Á., Mádai, F., Debreczeni, Á. (2015): Control of geopolymer properties by grinding of land filled flyash. International Journal of Mineral Processing, 143, 50 -58.

Mucsi, G., Szabó, R., Rácz, Á., Molnár, Z., Kristály, F., Kumar, S. (2015): Influence of red mud on the properties of geopolymer derived from mechanically activated lignite fly ash. In: Yiannis Pontikes (Ed.) Bauxite Residue Valorisation and Best Practices Conference. Leuven, Belgium, pp. 211-218.

Nenadovic, S. S., Mucsi, G., Kljajevic, L. M., Mirkovic, M. M., Nenadovic, M. T., Kristaly, F., Vukanac, I. S. (2017): Physicochemical, Mineralogical And Radiological Properties Of Red Mud Samples As Secondary Raw Materials. Nuclear Technology \& Radiation Protection: Vol. 32, No. 3, pp. 261-266.

Panias, D., Giannopoulou, I. P., Perraki, T. (2007): Effect of synthesis parameters on the mechanical properties of fly ash-based geopolymers. Colloids and Surfaces A: Physicochem. Eng. Aspects, pp. 246-254.

van Riessen, A., Jamieson, E., Kealley, C. S., Hart, R. D. and Williams, R. P. (2013): Bayer-geopolymers: An exploration of synergy between the alumina and geopolymer industries. Cement and Concrete Composites. 41, 29-33.

Singh, S., Biswas, R. D., Aswath M.U. (2016): Experimental Study on Red mud based Geopolymer Concrete with Fly Ash \& GGBS in Ambient Temperature Curing. International Journal of Advances in Mechanical and Civil Engineering, ISSN: 2394-2827. Special Issue, Sep.-2016, 5-8.

Vukcevic, M., Turovic, D., Krgovic, M., Boskovic, I., Ivanovic, M., Zejak, R. (2013): Utilization of geopolymerization for obtaining construction materials based on red mud. Materials and technology, 47, 1, 99-104. 


\section{SAŽETAK}

\section{Zajednička uporaba crvene isplake i mehanički nastaloga lebdećeg pepela u geopolimerima}

U radu je ispitana zajednička uporaba dvaju glavnih industrijskih otpada kod elektrana - lebdećega pepela i crvene isplake. Eksperimentalno je pokazano kako postoji korelacija između fizičkih svojstava dobivenih geopolimera te udjela takvih otpada. Stoga je ispitana uloga mehaničke aktivacije lebdećega pepela i udjela crvene isplake tijekom geopolimerizacije. Taj postupak načinjen je s različitim udjelima crvene isplake - od o do 30 težinskih postotaka. Tlačna čvrstoća geopolimera s lebdećim pepelom povećava se do $15 \%$ nakon dodavanja crvene isplake. Također su određeni i optimalni omjeri. Utjecaj isplake na fazni sastav i kemijske veze unutar geopolimera određen je XRD analizom i FTIR studijama. U njima su prepoznati novi minerali naziva hydroxycancrinit, faujasit i tenardit.

\section{Ključne riječi:}

crvena isplaka, lebdeći pepeo, mljevenje, geopolimer, čvrstoća, mineralne faze

\section{Authors contribution}

Gábor Mucsi (PhD, Associate Professor) provided the evaluation of the overall experimental results, interpretations and presentation of the results. Roland Szabó (Doctoral Candidate, researcher) provided the raw materials preparation and geopolymerization. Ádám Rácz ( $\mathrm{PhD}$, Assistant Professor) provided the evaluation of the grinding tests. Ferenc Kristály (PhD, Senior researcher) performed the x-ray diffraction analyses and its interpretation. Sanjay Kumar (PhD, Senior researcher) performed interpretation of the material structural results. 